\title{
Empowering elementary school students to become young nurses as movers and supervisors of healthy living behavior in SDIT Tahfizil Qur'an Islamic Centre Sumatera Utara
}

\author{
Farida Linda Sari Siregar $^{1^{*}}$, Lufthiani ${ }^{2}$, Asrizal $^{3}$ \\ ${ }^{1}$ Departemen Keperawatan Maternitas dan Keperawatan Anak, Universitas Sumatera Utara \\ ${ }^{2}$ Departemen Keperawatan Jiwa dan Komunitas, Universitas Sumatera Utara \\ ${ }^{3}$ Departemen Keperawatan Maedikal Bedah dan Keperawatan Dasar, Universitas Sumatera \\ Utara \\ Email*: farida.linda@ymail.com
}

\begin{abstract}
Empowering students as elementary school students to become young nurses is an activity that can improve students' knowledge and skills so that they can become movers and supervisors for healthy behavior in the school environment. The method used in this service is the training of young nurses, mentoring, and evaluation. The material presented in the training of young nurses is how to care for wounds, personal hygiene care, how to wash hands with soap properly, how to measure weight and height, how to maintain cleanliness of the school environment, how to recognize signs and symptoms of diarrheal disease, and intestinal worms. It is hoped that through this training students can become movers and supervisors for healthy living behaviors in schools. Young nurses who are trained are expected to be able to do wound care, measure height, measure weight, teach how to wash hands with soap and conduct health education to other students. The results of this community service activity showed that most students had good knowledge, good attitude and good skills after attending training on washing hands with soap. Students' skills on how to treat wounds showed mostly good after attending training on how to treat wounds. Students' skills on how to measure height and weight showed a good overall after attending training on how to measure height and weight.
\end{abstract}

Keyword: Empowerment, elementary students, young nurses.

\begin{abstract}
Abstrak
Pemberdayaan siswa sebagai Siswa SD Menjadi Perawat Cilik merupakan kegiatan yang dapat meningkatkan pengetahuan dan keterampilan siswa sehingga dapat menjadi penggerak dan pengawas perilaku hidup sehat di lingkungan sekolah. Metode yang digunakan dalam kegiatan pengabdian ini adalah pelatihan perawat cilik, pendampingan, dan evaluasi. Materi yang disampaikan dalam pelatihan perawat cilik adalah cara perawatan luka, perawatan kebersihan diri, cara mencuci tangan dengan sabun yang benar, cara mengukur berat badan dan tinggi badan, cara menjaga kebersihan lingkungan sekolah, cara mengenali tanda dan gejala penyakit diare, dan cacingan. Melalui pelatihan ini diharapkan siswa dapat menjadi penggerak dan pengawas perilaku hidup sehat di sekolah. Perawat cilik yang dilatih diharapkan dapat melakukan perawatan luka, mengukur tinggi badan, mengukur berat badan, mengajarkan cara mencuci tangan dengan sabun dan melakukan pendidikan kesehatan kepada siswa-siswa yang lain. Hasil dari kegiatan pengabdian ini menunjukkan sebagian besar siswa memiliki pengetahuan yang baik, sikap yang baik dan keterampilan yang baik setelah mengikuti pelatihan tentang cara mencuci tangan dengan sabun. Keterampilan siswa tentang cara merawat luka menunjukkan sebagian besar baik setelah mengikuti pelatihan tentang cara merawat luka. Keterampilan siswa tentang tentang cara mengukur tinggi badan dan berat badan menunjukkan seluruhnya baik setelah mengikuti pelatihan tentang cara mengukur tinggi badan dan berat badan.
\end{abstract}

Kata Kunci : Pemberdayaan, siswa SD, perawat cilik. 


\section{PENDAhuluan}

\subsection{Analisis Situasi}

Undang-undang Kesehatan No.23 thn 1992 pasal 45 menyatakan bahwa kesehatan sekolah diselenggarakan untuk meningkatkan kemampuan hidup sehat peserta didik dalam lingkungan hidup sehat sehingga peserta didik dapat belajar, tumbuh dan berkembang secara harmonis dan optimal menjadi sumber daya manusia yang berkualitas. Kegiatan di sekolah sebaiknya diarahkan untuk memupuk kebiasaan untuk hidup sehat agar memiliki pengetahuan, sikap dan keterampilan dalam melaksanakan prinsip hidup sehat serta aktif berpartisipasi dalam usaha peningkatan kesehatan baik di lingkungan sekolah, rumah, maupun masyarakat.

SD IT Tahfizil Qur'an Islamic Centre Sumatera Utara belum memiliki ruang UKS di sekolah, SD tidak pernah melakukan pendidikan kesehatan rutin, siswa juga belum mendapatkan pelatihan tentang Perawat Cilik. Siswa dan Siswi tidak pernah diberikan pengetahuan untuk melakukan pertolongan pertama pada kecelakaan (P3K), pengukuran berat badan dan tinggi badan tidak dilakukan secara rutin per 6 bulan, sekolah tidak memberikan pembinaan pada warung sekolah, kegiatan cuci tangan dengan sabun tidak pernah dilakukan secara rutin di sekolah, WC dan kamar mandi sekolah tidak di bersihkan secara rutin, tempat pembuangan sampah tidak memenuhi persyaratan kesehatan. Berdasarkan hasil observasi di halaman sekolah SD IT Tahfizil Qur'an Islamic Centre Sumatera Utara terdapat banyak debu terutama pada saat sore hari ketika siswa siswa bermain bola di halaman sekolah. Terdapat sampah berserakan di halaman sekolah karena sebagian besar siswa membuang sampah jajannya sembarangan. Tempat pembuangan sampah tidak dipisahkan antara sampah kering dan sampah basah dan tong sampah dalam keadaan terbuka. Penyajian makanan di kantin sekolah terlihat disajikan dalam keadaan terbuka. Di sekolah tidak tersedia wastapel untuk cuci tangan dan tidak tersedia sabun cuci tangan. Berdasarkan hasil wawancara dengan beberapa guru, mereka mengatakan bahwa siswa sering mengalami luka lecet akibat terjatuh pada saat bermain atau pada saat mengikuti pelajaran olahraga. Dalam penangannya pihak sekolah biasanya hanya menggunakan betadine tanpa membersihkannya dahulu, dan luka tidak ditutup dengan perban. Hal ini akan menyebabkan infeksi pada luka. Oleh karena pentingnya guru UKS dan siswa mendapatkan pengetahuan dan keterampilan tentang cara perawatan luka.

\subsection{Permasalahan Mitra}

Berdasarkan pengamatan dan wawancara kepada mitra, kepala sekolah menyatakan permasalahnnya sebagai berikut:

1. Siswa dan siswi tidak memiliki pengetahuan dan keterampilan dalam dalam melaksanakan kegiatan yang berkaitan dengan pemeliharaan, pertolongan dan perawatan kesehatan yaitu menjaga kebersihan diri, mengenal pentingnya imunisasi, mengenal bahaya penyakit diare, demam berdarah dan influenza, dan penyakit menular lainnya, merawat luka sederhana, cara mencuci tangan pakai sabun yang benar, membiasakan buang sampah pada tempatnya dan mengenal makanan sehat.

2. SD IT Tahfizil Qur'an Islamic Centre Sumatera Utara tidak memiliki sarana dan prasarana kesehatan yaitu tidak ada ruang UKS, tidak ada tempat tidur, tidak alat ukur Berat Badan dan Tinggi Badan, tidak ada alat-alat P3K, tidak ada alat peraga kesehatan, tempat pembuangan sampah yang terpisah dan tertutup dan tidak ada tempat cuci tangan.

\section{METODE PELAKSANAAN}

Pengabdian kepada masyarakat ini dilakukan melalui kegiatan pelatihan sebagai perawat cilik dengan metode:

a. Melakukan kegiatan pembentukan perawat cilik dengan menentukan kriteria yaitu:

- Siswa kelas 4 dan kelas 5

- Siswa yang berpenampilan bersih dan rapi

- Siswa yang memiliki perilaku sehat 
- Siswa yang memiliki tanggung jawab

- Siswa yang dapat berkomunikasi dengan baik

- Siswa yang bersedia menjadi perawat cilik

b. Melakukan persiapan alat untuk kegiatan pelatihan perawat cilik yang terdiri dari:

- Buku panduan perawat cilik

- Alat-alat Perawatan luka

- Sabun cuci tangan dan Tissue

- Membuat wastapel tempat cuci tangan

- Alat ukur Berat Badan dan Tinggi Badan

- Alat peraga kesehatan

- Obat-obatan

- Buku Catatan Kebersihan Diri Siswa

- Buku Catatan Kebersihan Lingkungan Sekolah

- Buku Catatan Kesehatan Siswa

c. Melaksanakan kegiatan pelatihan sebagai perawat cilik dengan metode pelatihan:

- Memberikan penjelasan

- Membaca mandiri

- Mendemonstrasikan

- Memutar Video

- Saling berdiskusi

- Bermain Peran

Materi yang disampaikan adalah:

- Perawatan luka sederhana

- Perawatan kebersihan diri

- Cara mencuci tangan dengan sabun yang benar

- Cara mengukur berat badan dan tinggi badan

- Cara menjaga kebersihan lingkungan sekolah

- Cara mengenali tanda dan gejala penyakit cacingan dan diare

d. Melakukan pendampingan kegiatan perawat cilik yang sudah dilatih dalam melakukan pengukuran tinggi badan dan berat badan, melakukan pertolongan pertama pada kecelakaan, dan cuci tangan dengan sabun

\section{HASIL DAN PEMBAHASAN}

Tahapan yang dilakukan dalam melaksanakan solusi permasalah Mitra

Tahap 1. Perencanaan, Kegiatan pengabdian kepada masyarakat ini diawali dengan melakukan koordinasi dengan kepala sekolah SDIT Tahfizil Qur'an Islamic Centre Sumatera Utara. Setelah mendapatkan persetujuan selanjutnya tim pengabdian masyarakat melakukan kerjasama dengan kepala sekolah dalam melakukan kegiatan pembentukan perawat cilik sesuai dengan kriteria yang telah ditentukan yaitu: siswa kelas 4 dan kelas 5 , siswa yang berpenampilan bersih dan rapi, siswa yang memiliki perilaku sehat, siswa yang memiliki tanggung jawab, siswa yang dapat berkomunikasi dengan baik, dan siswa yang bersedia menjadi perawat cilik. Jumlah siswa yang memnuhi kriteria ada 30 orang siswa.

Dari hasil pemilihan diperoleh karakteristik Siswa yang mengikuti pelatihan menjadi perawat cilik sebagian besar perempuan 17 orang siswa (56,7\%) dan berusia 9 tahun sebanyak 14 orang $(46,7 \%)$. Gambaran karakteristik siswa yang mengikuti pengabdian kepada masyarakat dapat dilihat pada tabel 1 . 
Farida Linda Sari Siregar et.al Empowering elementary school

Tabel 3.1. Distribusi Frekuensi Karakteristik Siswa SDIT Tahfizil Qur'an Islamic Centre

Sumatera Utara yang mengikuti pelatihan perawat cilik

\begin{tabular}{lcc}
\hline Karakteristik Siswa & f & $\mathbf{\%}$ \\
\hline Jenis Kelamin & & \\
- Laki-laki & 13 & 43,3 \\
- Perempuan & 17 & 56,7 \\
Usia & & \\
- 8 Tahun & 5 & 16,7 \\
- 9 tahun & 14 & 46,7 \\
- 10 tahun & 9 & 30 \\
- 11 tahun & 2 & 6,6 \\
\hline
\end{tabular}

Tahap.2 Melakukan pelatihan perawat cilik Pelatihan perawat cilik dilakukan dengan memberikan materi yang terdiri dari: Perawatan luka sederhana, Perawatan kebersihan diri, Cara mencuci tangan dengan sabun yang benar, Cara mengukur berat badan dan tinggi badan, Cara menjaga kebersihan lingkungan sekolah, Cara mengenali tanda dan gejala penyakit diare, dan cacingan.

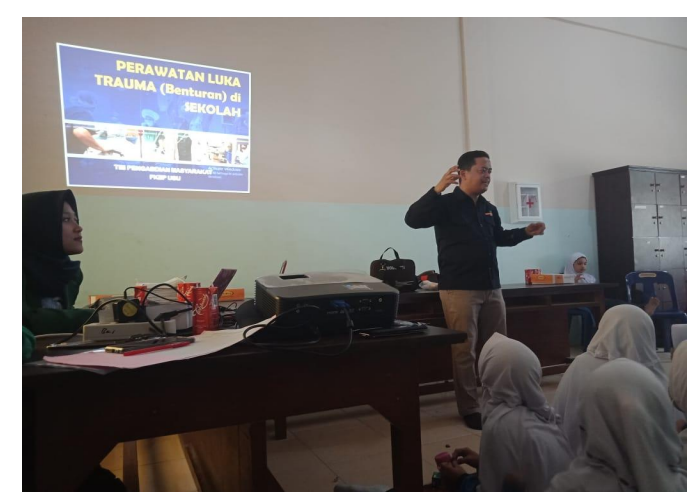

Gambar 3.1. Kegiatan menyampaikan materi cara perawatan luka

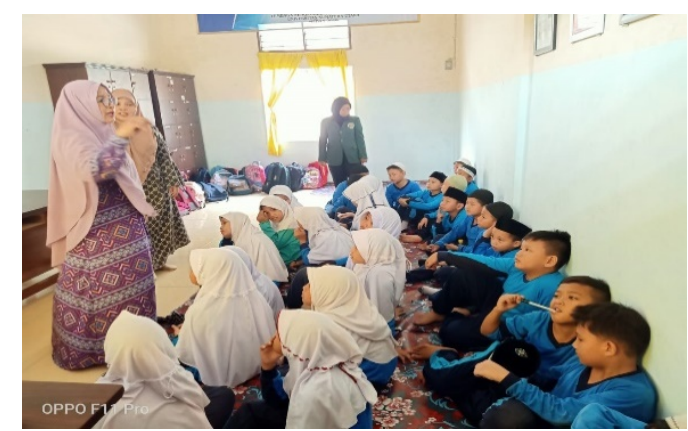

Gambar 3.2. Kegiatan menyampaikan materi cara menjaga kebersihan diri

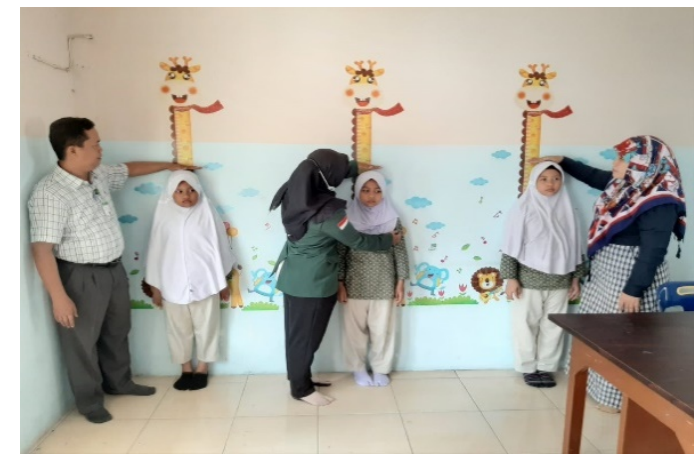

Gambar 3.3. Kegiatan mengajarkan cara mengukur tinggi badan 


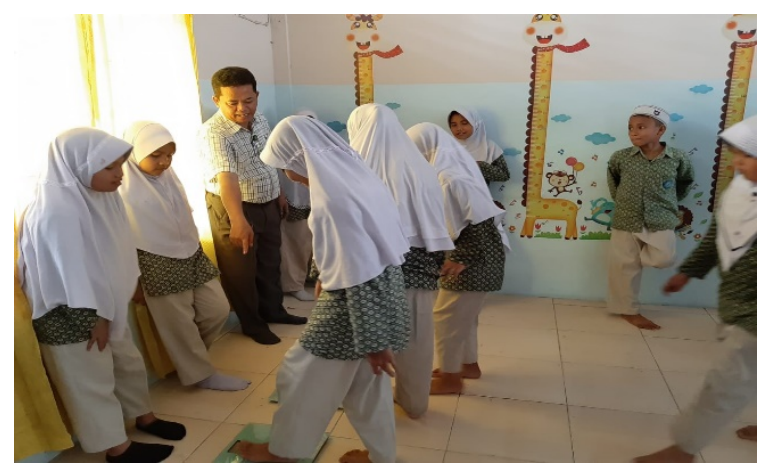

Gambar 3.4. Kegiatan mengajarkan cara mengukur berat badan

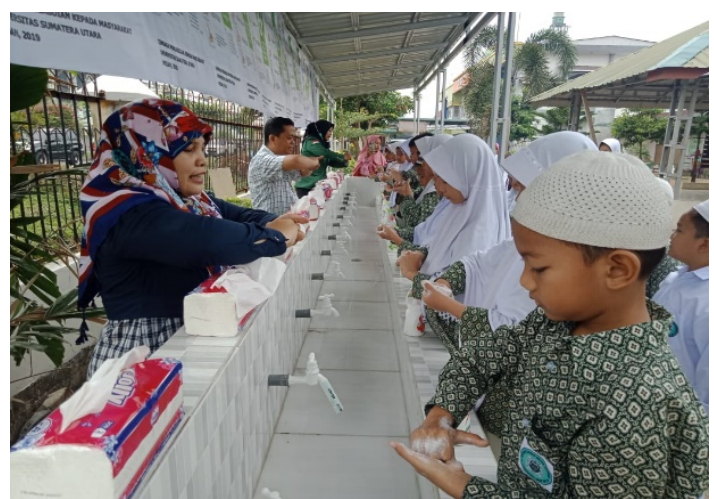

Gambar 3.5. Kegiatan mengajari cara mencuci tangan pakai sabun.

Tahap. 3 Melakukan pendampingan kegiatan perawat cilik yang sudah dilatih. Setelah dilakukan pelatihan selanjutnya tim melakukan kegiatan pendampingan perawat cilik yang sudah dilatih dalam pengukuran tinggi badan dan berat badan, mengajari cara mencuci tangan dengan sabun, cara merawat luka kepada teman-teman sekelasnya.

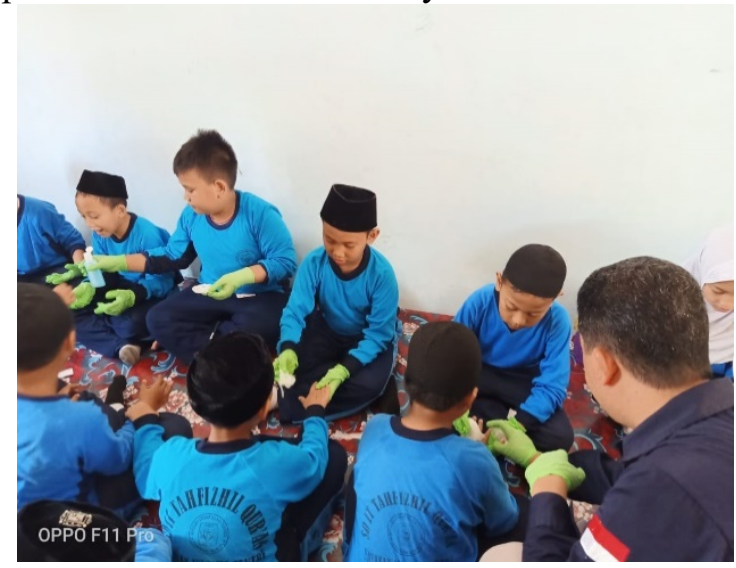

Gambar 3.6. Kegiatan pendampingan siswa dalam merawat luka 


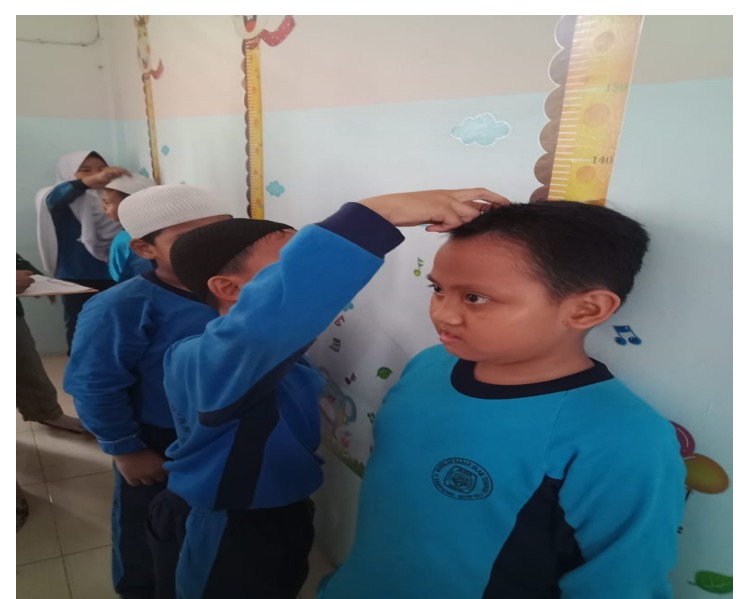

Gambar 3.7. Pendampingan siswa dalam melakukan pengukuran tinggi badan

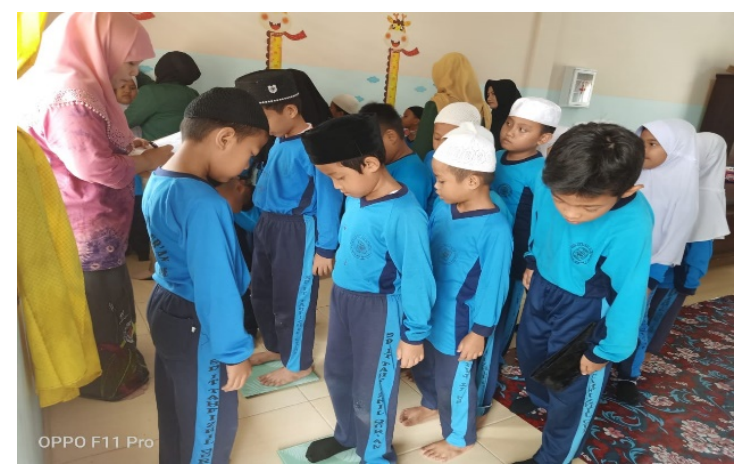

Gambar 3.8. Pendampingan siswa dalam melakukan pengukuran berat badan

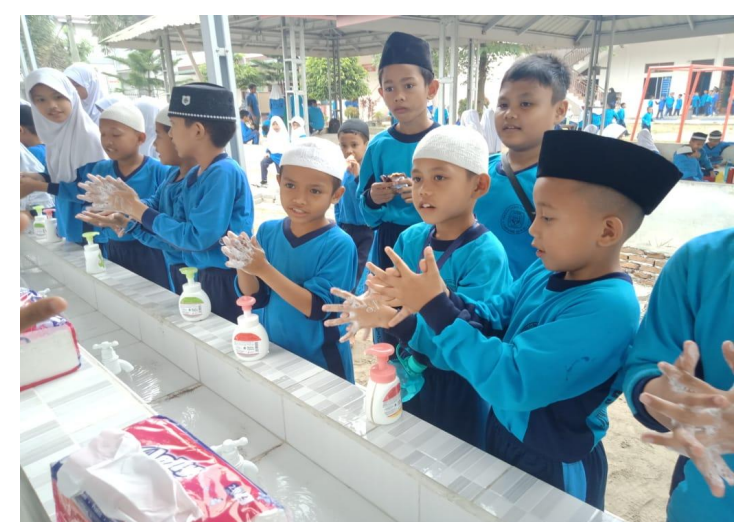

Gambar 3.9. Pendampingan siswa dalam melakukan cuci tangan pakai sabun

\section{Partisipasi Mitra dalam Pelaksanaan Program:}

1. Menyediakan tempat. Tempat yang disediakan adalah ruang UKS sebagai tempat pelatihan perawat cilik.

2. Menyediakan Siswa yang akan dilatih menjadi perawat cilik.

3. Siap menerima dan melaksanakan ilmu pengetahuan yang telah diberikan tim pengabdian kepada mitra untuk dijalankan secara berkelanjutan. 


\section{KESIMPULAN}

Kegiatan Pemberdayaan Siswa SD menjadi perawat cilik yang telah dilakukan dengan memberikan pelatihan perawat cilik dapat meningkatkan pengetahuan, sikap dan keterampilan siswa SD menjadi baik setelah diberikan pendidikan kesehatan tentang 6 langkah cara mencuci tangan dengan sabun, perawatan luka sederhana, cara mengukur tinggi badan dan berat badan, kebersihan diri dan lingkungan, tanda dan gejala cacingan dan diare, Perawat cilik yang sudah dilatih selanjutnya menyampaikan pendidikan kesehatan kepada teman-teman di sekolah untuk berperilaku hidup sehat, mengajari cara mencuci tangan dengan sabun, melakukan pengukuran tinggi badan dan berat badan kepada teman-teman disekolahnya serta membantu guru UKS dalam melakukan perawatan luka, pemeriksaan dan pengobatan kepada siswa yang sakit.

\section{UCAPAN TERIMAKASIH}

Tim pelaksana kegiatan pengabdian kepada masyarakat mengucapkan terima kasih kepada Lembaga Pengabdian Kepada Masyarakat USU yang telah mendanai kegiatan ini melalui skim pengabdian Mono Tahun Dosen Muda dengan sumber dana Non PNBP Universitas Sumatera Utara.

\section{DAFTAR PUSTAKA}

Haswita, Nuzula, F. (2018). Pembentukan Percil (Perawat Cilik) Sebagai Pionir Terdepan Guna Pencapaian Program Indonesia Sehat Cerdas. Warta Pengabdian, Volume 12, Issue 4, pp. 409416 doi: 10.19184/wrtp.v12i4.8720 (C) University of Jember, 2018 Published online Desember 2018.

Kementerian Pendidikan dan Kebudayaan Direktorat Jenderal Pendidikan Dasar. 2014. Pedoman Pelaksanaan UKS di Sekolah.

Kementerian Kesehatan Republik Indonesia. Petunjuk Teknis Pelaksanaan Sekolah/Madrasah Sehat Tingkat SD/MI

Kartika, M, Widagdo, L, Sugihantono A. (2016). Faktor-Faktor yang Berhubungan dengan Perilaku Cuci Tangan Pakai Sabun pada Siswa Sekolah Dasar Negeri Sambiroto 01 Kota Semarang. Jurnal Kesehatan Masyarakat (e-Journal) Volume 4, Nomor 5, Oktober 2016 (ISSN: 2356-3346). http://ejournal-s1.undip.ac.id/index.php/jkm

Nazria, Z, Shaluhiyah Z, Kusumawati A. (2018). Evaluasi Program Gerakan 21 Hari (G21h) Cuci Tangan Pakai Sabun Terhadap Perilaku Cuci Tangan Siswa di SD Islam Al-Azhar 14 Semarang. Jurnal Kesehatan Masyarakat (e-Journal) Volume 6, Nomor 1, Januari 2018 (ISSN: 2356-3346) http://ejournal3.undip.ac.id/index.php/jkm

Sari, Y.N. (2016). Perbedaan Perilaku Siswa SD tentang Cuci Tangan Pakai Sabun Sebelum dan Sesudah Penyuluhan Kesehatan dengan Metode Ceramah dan Demonstrasi serta Metode Ceramah dan Audio Visual di Kecamatan Langsa Kota Tahun 2016. http://repositori.usu.ac.id

Suharto E. 2009. Membangun Masyarakat Memberdayakan Rakyat. Bandung: Penerbit PT.Refika Aditama.

Undang-Undang Nomor 23 Tahun 1992 Tentang Kesehatan.

Widyaningrum R, Sitaresmi M.N, Lusmilasari L. (2016). Evaluasi Program Trias Usaha Kesehatan sekolah dan Perilaku Hidup Bersih dan Sehat di Sekolah Luar Biasa Bantul. Berita Kedokteran Masyarakat, Volume 32 No.9 Tahun 2016 